IRA-International Journal of Management \& Social Sciences

ISSN 2455-2267; Vol.12, Issue 02 (August 2018)

Pg. no. 31-40.

Institute of Research Advances

http://research-advances.org/index.php/RAJMSS

\title{
$\mathrm{RA}^{\text {mintatu a }}$

\section{A Study on Student Loan Schemes in India and Australia}

\author{
Sangeetha $P^{1 *}$ \& Dr. A. Raghurama ${ }^{2}$ \\ ${ }^{1}$ Research Scholar (UGC-SRF), Department of Studies in Commerce, Mangalore University, \\ Mangalagangothri-574199, India. \\ ${ }^{2}$ Retd. Professor, Department of Studies in Commerce, Mangalore University, \\ Mangalagangothri-574199, India. \\ \#corresponding author. \\ Type of Review: Peer Reviewed. \\ DOl: http://dx.doi.org/10.21013/jmss.v12.n2.p3
}

How to cite this paper:
Sangeetha P., Raghurama, A. (2018). A Study on Student Loan Schemes in India and Australia.
IRA-International Journal of Management \& Social Sciences (ISSN 2455-2267), 12(2), 31-40.
doi:http://dx.dol.org/10.21013/jmss.v12.n2.p3

(C) Institute of Research Advances.

(cc) EY-NC

This work is licensed under a Creative Commons Attribution-Non Commercial 4.0 International License subject to proper citation to the publication source of the work.

Disclaimer: The scholarly papers as reviewed and published by the Institute of Research Advances (IRA) are the views and opinions of their respective authors and are not the views or opinions of the IRA. The IRA disclaims of any harm or loss caused due to the published content to any party.

Institute of Research Advances is an institutional publisher member of Publishers International Linking Association Inc. (PILA-CrossRef), USA. The institute is an institutional signatory to the Budapest Open Access Initiative, Hungary advocating the open access of scientific and scholarly knowledge. The Institute is a registered content provider under Open Access Initiative Protocol for Metadata Harvesting (OAIPMH).

The journal is indexed \& included in WorldCat Discovery Service (USA), CrossRef Metadata Search (USA), WorldCat (USA), OCLC (USA), Open J-Gate (India), EZB (Germany) Scilit (Switzerland), Airiti (China), Bielefeld Academic Search Engine (BASE) of Bielefeld University, Germany, PKP Index of Simon Fraser University, Canada. 


\begin{abstract}
Higher education or tertiary education has been perceived as an important sector which contributes to the economic progress among the countries of the world. Higher education has grown rapidly, at the same time the cost of higher education is also rising throughout the world. Education loan or student loan schemes, as one of the sources of financing higher education, have been introduced in most of the countries. This paper attempts to understand and compare the student loan schemes introduced and implemented in India and Australia either through the commercial banks or through the government. The study concludes that the student loan procedures followed in other countries can also be considered with suitable modifications for the improvement of our education loan scheme at present.
\end{abstract}

Key Words: Commercial Banks, Cost, Higher Education Contribution Scheme, Education loan or student loan schemes.

\title{
INTRODUCTION
}

Student loan schemes have been introduced in many developed and developing countries to provide financial help to the needy students to pursue their tertiary education. Both India and Australia have introduced such student loan schemes. Australia, officially the Commonwealth of Australia, is the world's third most admired destination for international students for higher education after the US and the UK and education is its largest services export. There were about 500,000 international students studying in Australia in 2015. Students from China have contributed highest i.e., 27.3 percent, India was second, by contributing 10.8 percent of all international students in Australia. The Australian government introduced Higher Education Contribution Scheme (HECS), later it was absorbed into Higher Education Loan Program (HELP) to support the students' to participate in higher education by providing income-contingent concessional loans to assist them to meet the costs of education.

\section{REVIEW OF LITERATURE}

Rajinder Kaur and Manjit Singh (2012) tried to identify the challenges faced by bank managers in financing higher education. They have categorised various challenges to make well-informed decisions relating to the provision of funds for higher education. The data were collected from public and private sector banks operating in Punjab state of north India. The study revealed that in the stages of loan duration the stress level of the students and of the managers was different for the different level of income groups and urban students were more aware of higher education loan compared to rural students.

Nick Hillman (2014) considered the similarities and differences in student loans between UK and Australia on four areas, namely, Student loan entitlement, default rates, the balance between public and private contributions and repayment. The parameters of the two countries' student loan systems are different. The scope of tuition fee loans is broader in Australia than in England. The expected rates of non-repayment were lower in Australia compared to England. Both the countries have faced a particular challenge in the recovery of loans from former students living abroad. Australia does not extend support for tuition costs to students from other countries, as England is obliged to do under European Union (EU) rules. This paper focused on potential lessons for England, the rest of the UK and also for Australia.

Daniel Cooper and Christian Wang J. (2014) discussed two alternative methods of funding higher education and the cost of implementing the strategies for students compared to the current student loans model in the U.S. The Tertiary Education Levy (TEL) was an alternative model which was developed by the authors of this paper; that overcomes many of the limitations of the student loans funding model in the U.S. and the income contingent scheme (HECS) model in Australia. The model suggested also considered the benefits that both the individual (PRR-Private Rate of Return) and society (SRR-Social Rate of Return) gain from higher education. The repayments were based on the cost of the course and income earned but if they do not earn the income threshold they do not make repayments. There is a less financial burden on the graduate. It was found that the TEL model reduces the unmanageable levels of debt associated with other models and was likely to encourage a greater proportion of students from low socio-economic backgrounds to pursue higher education.

The above studies analysed the student loan schemes in India, comparison of student loan schemes between England and Australia; alternatives to Student Loans in Higher Education Funding in the US. This paper is an attempt to understand and compare the education loan schemes in India and the student loan schemes in Australia. 


\section{OBJECTIVES}

1. To understand the student loan schemes in India and Australia.

2. To compare the student loan schemes between the two countries.

3. To suggest measures to strengthen the existing loan scheme based on the findings.

\section{METHODOLOGY}

This study is based on the secondary data. The information and data are collected from articles in journals, books, IBA publications, internet sources and other related reports and publications.

\section{EDUCATION LOAN SCHEME IN INDIA}

The origin of the educational loan was the government-sponsored National Loan Scholarship Scheme, which was initiated in India in the year 1963. National Loan Scholarships were given free of interest to needy and meritorious students for full-time higher education in India, from post-matriculation till the completion of higher education. This scheme was continued till 1991. The scheme could not succeed as the rate of recovery was very low and also the country faced a severe economic crisis in the early nineties, due to which this scheme was discontinued. The Educational Loan Scheme was introduced in 2001. The Government of India in consultation with RBI and IBA (Indian Banks' Association) has framed a comprehensive Educational Loan Scheme, categorised under priority sector lending by the Commercial Banks in India.

\section{Education Loan Scheme}

The main objective of the Educational Loan scheme is no student shall be denied of the opportunity to pursue higher education for want of financial assistance. The repayment of the loan will be made from future earnings of the students after completion of their education.

* The eligibility criteria for the loan borrower include, student should be Indian national and should get admission to a higher education course in recognised institutions in India or abroad on merit basis either through entrance test or merit-based selection process after completion of ten plus two or equivalent education, the student is not able to bear the entire cost of higher education.

* Banks may prepare and publish a list of eligible courses in India and abroad, they would consider for sanctioning of loans, as the list of courses given in the loan scheme is indicative in nature. The courses for which banks sanction student loans will be decided by the individual bank which is based on employability and earning potential of the student after completion of the course and not on the parental income or family wealth.

* Education loans and advances will be granted up to a maximum of Rs.10 lakh for studies in India and Rs.20 lakh for studies abroad.

* No security is required up to a loan of Rs. 4 lakh and the parents to be the joint borrowers. For loans above Rs.4 lakh and up to Rs. 7.5 lakh collateral security in the form of suitable third party guarantee is taken and above Rs.7.5 lakh tangible collateral security of suitable value acceptable for the bank is also considered by the banks.

* Interest is charged at rates linked to the base rate as decided by the individual banks. $0.50 \%$ concession in interest for girl students will be given. $1 \%$ interest concession will be provided for servicing of interest during study/moratorium period.

* Expenses covered include: Fee payable to college/hostel, Examination/Library/ Laboratory fee, Travel expenses/ passage money for studies abroad, Purchase of books/ equipments/ instruments/ uniforms, computer etc.

* The margin will be: Up to Rs. 4 lakhs- Nil; Above Rs. 4 lakhs Studies in India 5\%; and Above Rs. 4 lakhStudies Abroad $15 \%$.

* Appraisal, Sanction and Disbursement of Loan: Applications will be received either directly at bank branches or through online mode. Generally, sanction or rejection of education loan application will be communicated within 15 days of receipt of duly completed application with supporting documents.

* The moratorium period/ repayment holiday is for the course period plus one year or six months after getting a job, whichever is earlier. In the normal course, loan applications have to be processed within a period of fifteen days to one month, but not exceeding the time norms stipulated for disposing of loan applications under priority sector lending.

* Repayment of the loan will be in equated monthly instalments for a period of 15 years for all categories. No prepayment penalty will be levied for prepayment of loan any time during the repayment period.

* Banks may make it mandatory to arrange for life insurance policy on the students availing Education Loan.

* Under the scheme, the Central Govt subsidises $100 \%$ of the loan's interest payable by the student belonging to an economically weaker section, during the study period/ before the commencement of repayment, should produce parents' income certificate issued by the concerned authority for income not exceeding Rs.4.50 lakh p.a. (w.e.f.1/4/2009). 


\section{STUDENT LOANS IN AUSTRALIA}

The higher education was free between 1974 and 1985 in Australia. Fees started to recur in 1985. The recommendations of the Wran Committee report (April 1988), were adopted and implemented by the government in 1989 as "the Higher Education Contribution Scheme (HECS)"; the loan element is described as a 'student contribution'. This scheme was introduced whereby all students would be responsible for paying tuition fees, even though on a deferred basis. The major concern for the adoption of HECS was to minimize financial disincentives and obstacles of the disadvantaged and to enhance their access towards Australian higher education.

\section{Commonwealth Supported Place (CSP)}

In Australia, a Commonwealth Supported Place (CSP) is a domestic higher education place at an institution which is subsidised by the Australian Government. Access to CSPs and Higher Education Loan Program (HELP) loans are not income tested; therefore, a student's assets or income will not affect their eligibility to access a HELP loan. These loans are not paid to a person's bank account. The government provides a direct subsidy to the educational institution for the CSP student under the Commonwealth grant scheme. It also pays the student contribution to the institution for those CSP students who defer their fees and get a HELP loan. A CSP is generally much cheaper than a fee-paying place. The majority of CSPs are offered in undergraduate courses and some CSPs are available at the postgraduate level because CSPs at this level are different across courses and institutions. A student who is not enrolled to a CSP is a fee-paying student, may use an FEE-HELP loan to pay their tuition fees. Higher Education Support Act 2003 governs the eligibility requirements for a CSP or HELP loan. An individual must be an Australian citizen, a New Zealand citizen or the holder of a permanent visa and will undertake at least one unit of study contributing to their course of study in Australia, or will be resident in Australia for the duration of their study can be eligible for CSP. An eligible student can apply for a CSP through the Tertiary Admissions Centre or may apply directly to the institution. In the student's enrolment letter, it will state whether they are being offered enrolment in a CSP or a fee-paying place. In order to apply for any of the HELP loans, a student will need their Tax File Number (TFN) or a valid Certificate of application for a TFN and a request for concerned HELP debt assistance form which is only available in the approved institutions/providers. The student must return this form to their institution by the census date; otherwise, they will not be entitled to a CSP or any of the HELP loans for that study period.

\section{Higher Education Contribution Scheme - Higher Education Loan Program}

Australia was the first country to introduce an income-contingent loan program for the payment of university fees, i.e., the Higher Education Contribution Scheme (HECS) in 1989, administered by the Department of Education. There were major reforms to higher education in 2003, which came into effect in 2005. HECS was absorbed into Higher Education Loan Programme (HELP) and is referred to as HECS-HELP since 2005. HELP loans are repaid through the tax system once a person earns over the compulsory repayment ceiling. HELP debts and repayments are managed by the Australian Taxation Office (ATO). The following table shows the various Phases of development of Australian Student Loan model.

Table 1: Australian Student Loan model: Phases of development

\begin{tabular}{|l|l|l|}
\hline \multicolumn{1}{|c|}{ Timing } & \multicolumn{1}{c|}{ Tuition fee regime } & \multicolumn{1}{c|}{ Loans availability } \\
\hline 1973-1986 & No tuition fees & None-no fees \\
\hline $\begin{array}{l}\text { Higher education contribution scheme } \\
\text { (HECS), 1989 }\end{array}$ & $\begin{array}{l}\text { Standard (delayed) tuition } \\
\text { fee }\end{array}$ & $\begin{array}{l}\text { Tuition loans for public sector } \\
\text { students }\end{array}$ \\
\hline Reforms of 1997 & $\begin{array}{l}\text { Higher (deferred) } \\
\text { differential fees }\end{array}$ & $\begin{array}{l}\text { Tuition loans for public sector } \\
\text { students }\end{array}$ \\
\hline Since 2005 & $\begin{array}{l}\text { Higher (deferred) } \\
\text { differential fees }\end{array}$ & $\begin{array}{l}\text { Loans extended to private sector } \\
\text { students }\end{array}$ \\
\hline
\end{tabular}

Source: Adrian Ziderman (2016)

\section{Higher Education Loan Programme (HELP)}

After the introduction of HELP by the Australian Government, the scope and coverage of the HELP scheme have grown to five constituent sub-programmes covering various types of loans to university and vocational education students. This loan programme helps eligible students to pay their student contributions (HECSHELP), tuition fees (FEE-HELP), student services and amenities fee (SA-HELP), overseas study expenses (OSHELP) and Vocational Education and Training fee (VET FEE-HELP). 
HECS-HELP is the loan scheme by Australian Government to help eligible Commonwealth-supported students to pay their 'student contribution' amounts, which is applicable to most domestic undergraduate students studying at Australian public universities. The student contribution amount is calculated by considering the number of units the student studies, the Equivalent Full-Time Student Load (EFTSL) of each unit, the price band to which the unit belongs and the year in which student began their study. Students enrolled in a CSP either have to pay their student contributions upfront or can access the HECS-HELP scheme to pay their student contributions. The amount of HECS-HELP an eligible student can access has no financial limit.

From 1989 to 1997, all students were charged a fixed contribution rate regardless of their course of study. In 1997 a differential system of 'bands' was introduced to consider both the different cost structures of disciplines and the different earning potential of graduates. There are three student contribution bands considering different areas of study with a minimum and maximum range that can be charged for units, normally, around 8 units in a band per year. For example, Student contribution for Band 2 includes Computing, built environment, other health, allied health, engineering, surveying, agriculture, mathematics, statistics, and science with Student contribution range per EFTSL of $\$ 0$ - $\$ 9,050$ for the year 2017. The institutions set the student contribution amount for each unit of study they offer, not exceeding the maximum rate set by the Government. Due to indexation the maximum band amounts slightly increases each year. Students, who paid the upfront payment of $\$ 500$ or more of their student contribution to the approved institution by the census date, received a $10 \%$ discount. This discount was removed from 1 January 2017. The study assist website lists the Student contribution bands and rates with a note applicable to the concerned units or courses.

\section{The FEE-HELP loan scheme}

This scheme was introduced to assist domestic fee-paying students to pay their tuition fees. A fee paying place is not subsidised by the Australian Government. Students who are enrolled in an eligible course of study in a fee-paying place at an institution or provider or through Open Universities Australia (OUA) charged tuition fees for their studies or is part of bridging studies for overseas-trained professionals; and meet the citizenship and/or residency requirements for the purpose by the census date are eligible for FEE-HELP, up to the FEE-HELP limit. Both in undergraduate and postgraduate courses at private higher education institutions and in postgraduate courses at universities, generally, fee paying places are offered. There is a lifetime limit on FEEHELP debt i.e., the total amount of FEE-HELP a person can use over their lifetime, which is the consolidated amount under both the FEE-HELP and VET FEE-HELP loan schemes. There is a 25 percent loan fee for undergraduate courses of study. The loan fee is calculated against the amount of FEE-HELP a student is receiving for the unit and added to a student's FEE-HELP debt.

\section{OS-HELP (Overseas-HELP) loan scheme}

OS-HELP loan scheme assists eligible undergraduate and postgraduate CSP students, who are enrolled in an accredited course of study to undertake a portion of their studies overseas. This scheme is introduced to help students for expenses, such as airfares, accommodation and other costs of study in a foreign country. These loans are paid by the Australian provider and in turn, reimbursed by the Government. An eligible student can also receive a supplementary loan amount to undertake language study, in preparation for overseas study in Asia. There is a limit of two OS-HELP loans for overseas study over a student's lifetime. One OS-HELP loan is available for a six-month period of study. The OS-HELP debt is required to be repaid by the students even if they do not complete their studies in Australia and/or overseas study for which the OS-HELP loan was borrowed.

\section{The SA (Student Services and Amenities)-HELP loan scheme}

The Australian Government introduced SA-HELP in 2011, to assist students to pay student services and amenities fees. SA-HELP loan scheme is for students who are eligible and enrolled at an approved institution with a desire to pay all or part of the student services and amenities fee with SA-HELP loan, up to the maximum fee charged for the relevant year to a full-time student. Students can borrow only this loan or can borrow this loan along with other HELP loans. Institutions can spend the fee only for services and amenities such as employment and career advice, sporting and recreational activities, financial advice, food services, and child care. They cannot spend the fee to/for supporting a political party, or the election of a person to a Commonwealth, state or territory, or local government body. In addition to this, the institutions must not require students to become a member of a student organisation.

\section{VET (Vocational Education and Training) FEE-HELP loan scheme}

The Australian Government introduced VET FEE-HELP in 2007, for eligible students studying higher level Vocational Education and Training (VET) courses with an approved provider by paying their tuition fees. In this scheme, an eligible course is a VET-accredited Diploma, advanced diploma, graduate certificate, and graduate 
diploma; it also to be extended to selected certificate IV qualifications in certain states/territories for a trial period. Any amount borrowed by the student under either VET FEE-HELP or FEE-HELP should not exceed the FEE-HELP limit. There is a loan fee of 20 percent for all courses for fee-paying students. The VET FEE-HELP scheme which ceased for new students on 31 December 2016 was replaced by VET Student Loans from 1 January 2017.

\section{Citizenship, residency \& Tax File Number (TFN) requirements:}

The domestic students who meet the citizenship, residency or TFN requirements, enrolled with an approved institution/provider are eligible to enrol in a CSP or access a HELP loan to pay for their student contributions/tuition fees. According to the Australian Citizenship Act 2007, a person may acquire Australian citizenship by birth or adoption in Australia or may apply to acquire Australian citizenship. Along with these requirements, the students have to meet the specified conditions under the concerned HELP loan schemes to be eligible to get the required HELP loan.

Census date: In accordance with the legislation, institutions set the date which is the deadline for a student to meet various requirements, is 'Census date'. An eligible student can make an upfront payment of their tuition fees, submit a request for Commonwealth assistance form to access a HELP loan or withdraw their enrolment without incurring tuition fees for that unit by the given date. On the basis of rules set by the Australian Government, approved institutions can set their own census dates. Normally, these institutions publish the census dates on their website; which will vary across institutions and courses.

The administrative date: Administrative date is a date set by approved institutions for the students to meet certain requirements before the census date. The students can contact the student administration or enrolments office at their institution to determine the census date and an administrative date that applies to them if their institution has set both dates.

\section{REPAYMENT OF HELP DEBTS}

All HELP loans are considered an accumulated HELP debt and are consolidated at the Australian Taxation Office (ATO). HELP debt repayment is income contingent subject to level of borrower's income; it is progressive with temporary exemption for low earning graduates. When a person's repayment income is above the minimum repayment threshold for compulsory repayment, starts repaying his accumulated HELP debt, even if the person is still studying. This threshold is adjusted in each income year. For the income year 2015-16, the threshold was $\$ 54,126$ and for $2016-2017$ it was $\$ 54,869$. Student loans from the separate sub-programmes are combined into single pool of loans that are owed to the government. Repayments are made towards a person's accumulated HELP debt, not each separate HELP loan the person has accessed, i.e., for example, a person cannot choose to pay off their SA-HELP debt first and then FEE-HELP debt etc. The Repayment rates over the threshold as a percentage of total income for the year 2016-17 are as follows:

Table 2: Repayment rates for the 2016-17 income year

\begin{tabular}{|c|c|}
\hline Repayment income (\$) & Repayment rate (\%) \\
\hline Below 54,869 & Nil \\
\hline $54,869-61,119$ & 4.0 \\
\hline $61,120-67,368$ & 4.5 \\
\hline $67,369-70,909$ & 5.0 \\
\hline $70,910-76,222$ & 5.5 \\
\hline $76,223-82,550$ & 6.0 \\
\hline $82,551-86,894$ & 6.5 \\
\hline $86,895-95,626$ & 7.0 \\
\hline $95,627-101,899$ & 7.5 \\
\hline 101,900 and above & 8.0 \\
\hline
\end{tabular}

Source: Australian Govt. Commonwealth supported places and HECS-HELP information booklet, 2017

The student loan borrower repays his or her HELP loan to the Australian Taxation Office. The repayments rates are set annually by the government. Repayment amounts are calculated as a percentage of a person's income and have no bearing on the income of the person's parents or spouse. Repayment is not tax deductible. According to taxable income of the person, the rate at which the HELP debt is repaid will increase. The more a person earns, his repayment percentage will be the higher, up to 8 percent. The length of the time taken for individual borrowers to repay their loans varies widely depending on individual circumstances. HELP loans are currently repaid by borrowers over an average of 9 years. A person's compulsory repayment for the year will be calculated by the ATO and includes that on their income tax notice of assessment. Compulsory repayments will 
be continued until a person has repaid his entire HELP debt. The ATO issues TFN (tax file number), a unique identification number for all tax-related purposes, making HELP debt repayments.

There is no interest charged on HELP debts. The outstanding HELP loan balances increase only by the amount of CPI or inflation. These outstanding balances are indexed annually by the Consumer Price Index (CPI). The HELP debt more than 11 months old is subject to indexation which is applied on $1^{\text {st }}$ June every year. HELP debts are indexed to retain the real value of the debt by adjusting it corresponding to changes in the cost of living which is measured by the Consumer Price Index (CPI). HELP loans are provided to students on a concessional basis as CPI inflation i.e., the rate of interest, is typically lower than the Government's cost of borrowing. Government subsidy is equal to the difference between the government's cost of borrowing and the prevailing rate of inflation. Students pay the real value of the loan i.e. interest $=$ inflation. The ATO website publishes the indexation rates and all HELP debts are managed by the ATO.

\section{COMPARISON OF STUDENT LOAN SYSTEM BETWEEN INDIA AND AUSTRALIA}

The student loan scheme in India and Australia are compared based on different criteria followed in both the countries. The following table exhibits the comparison of student loan schemes between India and Australia.

Table 3: Comparison of Student Loan Schemes between India and Australia

\begin{tabular}{|c|c|c|}
\hline Criteria & India & Australia \\
\hline $\begin{array}{l}\text { Name of the } \\
\text { scheme }\end{array}$ & Education Loan Scheme & Higher Education Loan Programme (HELP) \\
\hline $\begin{array}{l}\text { Implementation } \\
\text { year }\end{array}$ & 2001 & 1989 \\
\hline Product type & Loan & Loan \\
\hline Eligibility & $\begin{array}{l}\text { The student should be Indian national, should get } \\
\text { admission to a higher education course in recognised } \\
\text { institutions in India or abroad after completion of ten } \\
\text { plus two or equivalent; must be a meritorious student; } \\
\text { and economically poor }\end{array}$ & $\begin{array}{l}\text { An Australian citizen, a New Zealand citizen or the holder of } \\
\text { a permanent visa; enrolled in an eligible course at an } \\
\text { approved institution. } \\
\text { A domestic student who meets the eligibility requirements for } \\
\text { either a CSP and/or HELP loan. }\end{array}$ \\
\hline Courses eligible & $\begin{array}{l}\text { Professional degrees, postgraduate, graduate degrees, } \\
\text { diplomas offered by recognized institutions }\end{array}$ & $\begin{array}{l}\text { Graduate/postgraduate courses in public institutions. A } \\
\text { tertiary institution that offers accredited higher education } \\
\text { courses }\end{array}$ \\
\hline Target group & $\begin{array}{l}\text { Meritorious, poor students in recognized public or } \\
\text { private higher education institutions in India/ abroad }\end{array}$ & $\begin{array}{l}\text { Students enrolled in an eligible course at an approved } \\
\text { institution. Students opt either to pay their fees upfront or to } \\
\text { defer payment and take out a HELP loan from the } \\
\text { government. }\end{array}$ \\
\hline $\begin{array}{l}\text { Mode of Loan } \\
\text { grant }\end{array}$ & Student's bank account & $\begin{array}{l}\text { Australian Government pays students' contributions/tuition } \\
\text { fees, directly to their institution on the student's behalf }\end{array}$ \\
\hline $\begin{array}{lr}\text { Grant } & \text { size/ } \\
\text { quantum } & \text { of } \\
\text { finance }\end{array}$ & $\begin{array}{l}\text { Need-based finance; maximum of Rs.10 lakh for studies } \\
\text { in India and Rs. } 20 \text { lakh for studies abroad }\end{array}$ & $\begin{array}{l}\text { There is no financial limit to the amount of HECS-HELP an } \\
\text { eligible student can access. As this is a separate loan scheme } \\
\text { to FEE-HELP, any amounts borrowed under HECS-HELP } \\
\text { will not count towards the FEE-HELP limit. }\end{array}$ \\
\hline $\begin{array}{l}\text { Expenses } \\
\text { Covered }\end{array}$ & $\begin{array}{l}\text { Fee payable to college/hostel, Library/Examination/ } \\
\text { Laboratory fee, Travel expenses/ passage money for } \\
\text { studies abroad, Purchase of books, computer, etc }\end{array}$ & $\begin{array}{l}\text { Student contributions (HECS-HELP), tuition fees (FEE- } \\
\text { HELP), student services and amenities fee(SA-HELP), } \\
\text { overseas study expenses (OS-HELP) and Vocational } \\
\text { Education and Training fee (VET FEE-HELP) }\end{array}$ \\
\hline Repayment time & $\begin{array}{l}\text { For loans upto Rs. } 7.5 \text { lakhs- upto } 10 \text { years; For loans } \\
\text { above Rs. } 7.5 \text { lakhs - upto } 15 \text { years (September 2012); } \\
\text { Repayment of the loan will be in equated monthly } \\
\text { instalments for a period of } 15 \text { years for all categories } \\
(2015)\end{array}$ & $\begin{array}{l}\text { When their income is above the minimum repayment } \\
\text { threshold for compulsory repayment. The length of the time } \\
\text { taken for individuals to repay their loans varies widely } \\
\text { depending on individual circumstances. HELP loans are } \\
\text { currently repaid by borrowers over an average of } 9 \text { years. }\end{array}$ \\
\hline $\begin{array}{l}\text { Repayment } \\
\text { holiday/ } \\
\text { moratorium }\end{array}$ & $\begin{array}{l}\text { Course period }+1 \text { year or } 6 \text { months after getting a job, } \\
\text { whichever is earlier. }\end{array}$ & $\begin{array}{l}\text { When their repayment income is above the minimum } \\
\text { repayment threshold for compulsory repayment, even if the } \\
\text { person is still studying. }\end{array}$ \\
\hline Repayment way & $\begin{array}{l}\text { Monthly installments; Accrued interest will be added to } \\
\text { the principal amount borrowed while fixing EMI for } \\
\text { repayment }\end{array}$ & $\begin{array}{l}\text { A person's compulsory repayment for the year will be } \\
\text { calculated by the ATO and includes that in their income tax } \\
\text { notice of assessment. Borrower repays HELP loan to the } \\
\text { ATO. }\end{array}$ \\
\hline $\begin{array}{l}\text { Guarantor/ } \\
\text { Security } \\
\text { requirement }\end{array}$ & $\begin{array}{l}\text { Up to Rs. } 4 \text { lakh-the parents to be the joint borrowers; } \\
\text { above Rs. } 4 \text { lakh and up to Rs. } 7.5 \text { lakh - parents, } \\
\text { collateral security in the form of suitable third party }\end{array}$ & $\begin{array}{l}\text { A student can apply for a CSP through the Tertiary } \\
\text { Admissions Centre or directly to the institution. In the } \\
\text { student's enrolment letter, it will state whether they are being }\end{array}$ \\
\hline
\end{tabular}




\begin{tabular}{|c|c|c|}
\hline & $\begin{array}{l}\text { guarantee and above Rs.7.5 lakh tangible collateral } \\
\text { security of suitable value. }\end{array}$ & $\begin{array}{l}\text { offered enrolment in a CSP or a fee-paying place. } \\
\text { Students need TFN and a request for concerned HELP debt } \\
\text { assistance form which is available with approved } \\
\text { institutions/providers. }\end{array}$ \\
\hline $\begin{array}{l}\text { Appraisal/ } \\
\text { sanction/ } \\
\text { disbursement }\end{array}$ & $\begin{array}{l}\text { Applications will be received either directly at bank } \\
\text { branches or through online mode; Students may submit } \\
\text { their loan applications either at the bank branches near } \\
\text { to the residence of parents or to the educational } \\
\text { institution; while appraising the loan, the future income } \\
\text { prospect of the student only will be looked into; } \\
\text { sanction/rejection will be communicated within } 15 \text { days } \\
\text { of receipt of duly completed application with supporting } \\
\text { documents. }\end{array}$ & $\begin{array}{l}\text { Student should submit a request for Commonwealth } \\
\text { assistance to access a HELP loan. Each type of HELP loan } \\
\text { requires the eligible students to submit their TFN and a } \\
\text { request for concerned HELP debt assistance form to their } \\
\text { institution by the census date, otherwise, they will not be } \\
\text { entitled to a CSP or any of the HELP loans for that study } \\
\text { period. }\end{array}$ \\
\hline Interest rate & $\begin{array}{l}\text { Interest is charged at rates linked to the base rate as } \\
\text { decided by the individual banks; Simple interest to be } \\
\text { charged during the study period and up to } \\
\text { commencement of repayment; } 0.50 \% \text { concession in } \\
\text { interest for girl students; } 1 \% \text { interest concession may be } \\
\text { provided, if interest is serviced during the study period; } \\
\text { Deduction under } 80 \mathrm{E} \text { of income tax act is available for } \\
\text { Interest paid on education loan. }\end{array}$ & $\begin{array}{l}\text { Interest rate is equal to Consumer Price Index (CPI). } \\
\text { Repayments are not tax deductible. }\end{array}$ \\
\hline $\begin{array}{l}\text { Administrative } \\
\text { body }\end{array}$ & $\begin{array}{l}\text { All scheduled public/private sector banks as per IBA } \\
\text { regulations }\end{array}$ & Department of Education, and ATO \\
\hline Interest subsidy & $\begin{array}{l}\text { Available to EWS Students during moratorium period } \\
\text { who produce parents income certificate issued by the } \\
\text { authority concerned, not exceeding Rs. } 4.50 \text { lakh p.a. } \\
\text { Central govt subsidises } 100 \% \text { of the loan's interest } \\
\text { during the study period / subsequent moratorium period } \\
\text { before the commencement of repayment (2009) }\end{array}$ & $\begin{array}{l}\text { The government provides a direct subsidy to the educational } \\
\text { institution for the CSP student under the Commonwealth } \\
\text { grant scheme. } \\
\text { The student loan is indexed in CPI. The loan is concessional } \\
\text { because CPI inflation (the rate of interest payable by the } \\
\text { student) is typically lower than the Government's cost of } \\
\text { borrowing. }\end{array}$ \\
\hline Constraints & Default risk, adequacy, etc & Default risk \\
\hline
\end{tabular}

Source: Compiled from Model Education loan scheme, India and various student loan schemes in Australia.

The above table 3 shows the major differences and similarities between the education loan schemes and the constraints faced by the two countries. The major similarities are: the scheme is framed to provide financial help to pursue higher education for the needy students who are the citizens of the respective country. The default risk is the main constraint faced by both the countries.

The major differences observed are: the commercial banks are authorised to execute the loan scheme in India, whereas in Australia, Department of Education administers the student loan scheme. The target group for the loan under HELP is students in Commonwealth Supported Places (CSP) in public and in some private HEIs whereas, in India, it is the students in both public and private institutions with recognition. In Australia, a student can apply for a CSP through the Tertiary Admissions Centre or may apply directly to the institution. In India loan applications are directly submitted to the banks by the students.

In India, education loan amount is directly credited to the student's bank account and it becomes due for repayment after the repayment holiday; repayment will be in equated monthly installments (EMIs). Australian Government pays students' contributions/tuition fees, directly to their institution on the student's behalf. HELP debt repayment is income contingent, subject to the level of borrower's income; the borrowers repay their HELP loan to the Australian Taxation Office (ATO). Education loan is available for studies both in India and abroad. Expenses related to the studies are covered in this scheme. In Australia, various schemes are available, namely, Student contributions (HECS-HELP), tuition fees (FEE-HELP), student services and amenities fee (SA-HELP), overseas study expenses (OS-HELP) and Vocational Education and Training fee (VET FEE-HELP).

Under HELP, The government provides a direct subsidy to the educational institution for the CSP student under the Commonwealth grant scheme. But in India, the interest subsidy is available to students from the economically weaker section, with parents' income certificate issued by the authority concerned, which is not exceeding Rs.4.50 lakh p.a. In India, simple interest is charged during the study period up to the commencement of repayment. $0.50 \%$ concession in interest for girl students will be provided; whereas in Australia, no interest is charged on HELP debts. The outstanding HELP loan balances increase only by the amount of CPI or inflation i.e., the Interest rate is equal to CPI. 


\section{SUGGESTIONS TO STRENGTHEN THE EDUCATION LOAN SCHEME IN INDIA}

Certain measures can be considered to strengthen education loan scheme in India:

$>$ Higher educational institutions are also the potential beneficiaries of the loan. They can take initiatives in promoting the student loan operation, create credit awareness in students, gather information, guide and help the students in obtaining a loan so that more and more needy students can be benefitted out of the scheme.

$>$ Higher educational institutions can also present the required documents to the bank; help to track the loan beneficiaries after completion of their studies and help the banks in recovery of loans.

$>$ According to some studies/reports, though the Government of India promises $100 \%$ reimbursement of interest in the case of economically weaker students, in reality, only a small portion was being paid to students. The concerned authorities should take necessary steps to give this benefit to the students who deserve it.

$>$ Bankers and educational institutions of the students should keep track of the students who availed loan and should guide the students in getting the job to repay the loan.

$>$ In the case of students who borrowed education loan and who are employed after the completion of their higher education bankers should keep track of such students through educational institutions and their parents so as to avoid wilful defaults.

$>$ The rate of interest should be reduced; the disparity in the rate of interest should be removed and rate of interest should be kept within certain range applicable to all banks under priority sector lending.

$>$ The creditworthiness of students who seek education loan and their parents must be strictly assessed.

$>$ Bankers must ensure that the loan is utilised for higher education purpose. The marks cards of students must be insisted particularly to ensure the progress made by the students and also to see that the students are pursuing their education.

\section{CONCLUSION}

Student loan as a source of financing higher education plays an important role in increasing access to tertiary education especially among students from families of low socio-economic status in India and Australia. The Students are provided sufficient funds in time to continue and complete their higher education. The student loan procedures followed in other countries can also be considered for the improvement of our education loan scheme at present. The pros and cons of such procedures can be tested in the light of the present economic situation of the country. With suitable modifications, such procedure can be adopted to ensure that the needy students will get the higher education which shapes their life as well as contributes to the development of the economy.

\section{References}

[1]. Adrian Ziderman (2016) "Student loan schemes in Practice: A Global Perspective" in Student Financing of Higher Education: A Comparative Perspective, eds. Donald E. Heller and Claire Callender, pp.32-60.

[2]. Alex Usher (2005), Global Debt Patterns: An International Comparison of Student Loan Burdens and Repayment Conditions. Toronto, ON Educational Policy Institute, Canadian Higher Education Report Series.

[3]. Daniel Cooper and J. Christian Wang (2010) "What Are the Alternatives to Student Loans in Higher Education Funding?", Contemporary Issues In Education Research, Vol. 3 (1), January, pp.19-30.

[4]. Daniel Cooper and J. Christina Wang (2014) "Student Loan Debt and Economic Outcomes", Current policy perspectives, Federal Reserve Bank of Boston, No.14-7, October, pp.1-37.

[5]. Higher Education Loan Program (HELP) and other student loans: a quick guide. Retrieved from http://apo.org.au/system/files/76285/apo-nid76285-31241.pdf

[6]. Higher Education Loan Programme-HELP, Impact on the Budget, Parliamentary Budget Office, Report no. 20/2016. Retrieved from https://www.aph.gov.au/

[7]. http://mhrd.gov.in/university-and-higher-education

[8]. http://studyassist.gov.au/sites/StudyAssist/HelpfulResources/Documents/2017_HECS-HELP_Booklet_ACC.pdf

[9]. http://www.iba.org.in/Documents/Amended_Guidance_Notes_Augsut_2105.pdf

[10]. http://www.iba.org.in/Documents/Model_Edu_loan.pdf

[11]. https://dfat.gov.au/about-us/publications/Documents/australia-in-brief.pdf

[12]. https://www.studyassist.gov.au/helpful-resources/publications-help-booklets

[13]. https://www.studyassist.gov.au/help-loans-and-csps/

[14]. https://www.studyassist.gov.au/help-loans-and-csps-commonwealth-supported-places/student-contributionamounts

[15]. https://www.studyassist.gov.au/sites/studyassist/files/2016_csp_help_handbook.pdf

[16]. https://www.studyassist.gov.au/sites/studyassist/files/2016_vet_fee-help_booklet_-_updated_july_16.pdf

[17]. Maureen Woodhall (1991). Student loans in higher education- Asia, International Institute for Educational Planning (IIEP) educational forum, UNESCO, Paris.

[18]. Nick Hillman (2014) "A Comparison of Student Loans in England and Australia", Higher Education Policy Institute (HEPI) Report 66. Retrieved from http://www.hepi.ac.uk/wp-content/uploads/2014/04/FINALAUSTRALIA-PIECE.pdf 
[19]. Rajinder Kaur \& Manjit Singh (2012), "Higher Education Finance Challenges: A Structural Equation Approach", Journal of Educational Science and Research (JESR), Vol.2 (1), June, pp.10-29.

[20]. The Australian Education System - Practitioner Level. Retrieved from http://dfat.gov.au/aid/topics/investmentpriorities/education-health/education/Documents/australian-education-system-practitioner.pdf

[21]. www.iba.org.in/Documents/revisededuscheme21092012_04_10_12.doc. 